DE DE GRUYTER OPEN
Przedsiębiorczość i Zarządzanie Entrepreneurship and Management University od Social Sciences Publishing House ISSN 1733-2486

Volume XVI, Issue 1, pp. 23-37

DOI 10.1515/eam-2015-0002

Małgorzata Magdalena Hybka

University of Economics in Poznan

\title{
Casino Taxation in a Normative and Economic Context: the Case of Poland
}

\begin{abstract}
:
The aim of this article is twofold. First, it provides an overview of theoretical background of casino taxation. Second, it analyses the provisions of the Act regulating casino taxation in Poland and evaluates the consequences of the new Gambling Law in force since 2010. The first section of it discusses motives, outcomes and forms of casino taxation, taking into account inter alia the assumptions of optimal tax theory. It then deals with Polish regulations concerning the organisation of gambling in casinos and gambling tax design. The last section of the article analyses the scale of operation of Polish casinos, their revenues and the tax due on gambling activities.
\end{abstract}

Key words: casino, taxing externalities, excise duties, commercial gambling.

\section{Introduction}

Commercial gambling has been a rapidly growing industry in the world economy over the last three decades. According to the report issued by Global Industry Analysts in 2011 casino gaming represents the largest and the most lucrative segment of the commercial gambling market [MCP-1050: Casinos, online]. It is estimated that casinos make up one third of the gambling market's gross turnover, which amounted to 305 billion euros in 2013. Moreover, in the years 2006-2013 the global casino gaming revenue increased by nearly $60 \%$. Out of the 3,547 legally operated casinos throughout the world in 2011 - 1,623 offered their services in North America, 682 - in Western Europe and 479 - in Eastern Europe. 
Gambling is more or less socially acceptable depending on the cultural environment. Moral concerns are likely to arise because gambling has some negative effects on society. Above all even irregular gambling may lead to addiction (problem gambling or even pathological gambling). Secondly it is associated with an increased crime rate. Several studies have shown that arrest rates for criminal offences are significantly higher for gamblers than for nongamblers [Emshoff 2008, pp. 2-6]. On the other hand the gambling industry is proven to benefit local economies [Mallach 2010, pp. 11-19]. For these reasons governments impose restrictions on gambling and decide about the scale and form of the gambling industry. In addition gambling products tend to be subject to quite high explicit and implicit tax rates approximating those levied on tobacco and alcohol the basic purpose of which is to discourage forms of consumption that are not favoured by public opinion [Cnossen 2005, p. 601; Clotfelter 2005, p. 85].

Commercial gambling is also subject to numerous limitations in Poland. Since 2010 a new law has regulated licensing procedures and the taxation of the gambling market. Some of the regulations are claimed to have a discriminatory character and infringe the European Union law. As a result on November 20th, 2013 an official request for information on the national legislation restricting the supply of gambling services was sent by the European Commission to the Polish government.

The article is devoted to casino taxation in Poland. It attempts to answer three questions:

- what are the theoretical concepts of casino taxation?

- to what an extent are these concepts taken into account while designing tax policy?

- what are the consequences of the new Gabling Law in Poland in force since 2010?

As the Polish literature on the gambling tax is very scarce the theoretical part of the article is based on the literature analyzing the functioning of the foreign gambling markets. The second part of the article reviews the current restrictions imposed in Poland on gambling operators, categories of levies paid by them, the regulations defining the gambling tax base and concerning tax rates and gambling taxpayers' obligations. The last part contains an analysis of statistical data of the Ministry of Finance concerning the number of casino operators, their revenue and the tax paid by entities organizing gambling games and mutual bets in Poland before and after the introduction of the new Gambling law. 


\section{Concepts of Casino Taxation}

Although gambling taxes are comparable in structure to other common excise duties (e.g. excise duties imposed on alcohol or tobacco) gambling operators tend to be taxed at rates over and above those of typical businesses offering excise liable goods [Philander 2013, p. 17]. Moreover there are some distinct features of the gambling sector that may explain the need for a specific design of gambling tax. D. Forrest indicates three of these features [2008, pp. 542-543]:

- there is no natural unit of gambling services consumption equivalent to a unit of alcohol or single cigarette (the tax base may be hardly defined in physical quantities as counting the number of bets placed in a period has little meaning if the bets are different in value),

- price is conceptually difficult to define as whilst gambling the player is willing to lose a certain amount of money in return for excitement or diversion; the win/loss varies from occasion to occasion and is known ex post,

- in the case of drinking and smoking social costs are correlated with levels of physical consumption; although to some extent the scale of social problems arising from dysfunctional gambling may be connected with the time spent on gambling, most harm that comes from gambling is related to financial pressure on the household itself; as a result taxation that reflects social cost should be based on the impact on the player's expenditure rather than on the quantity. 


\section{Figure 1. Market Analysis of a Casino Game}

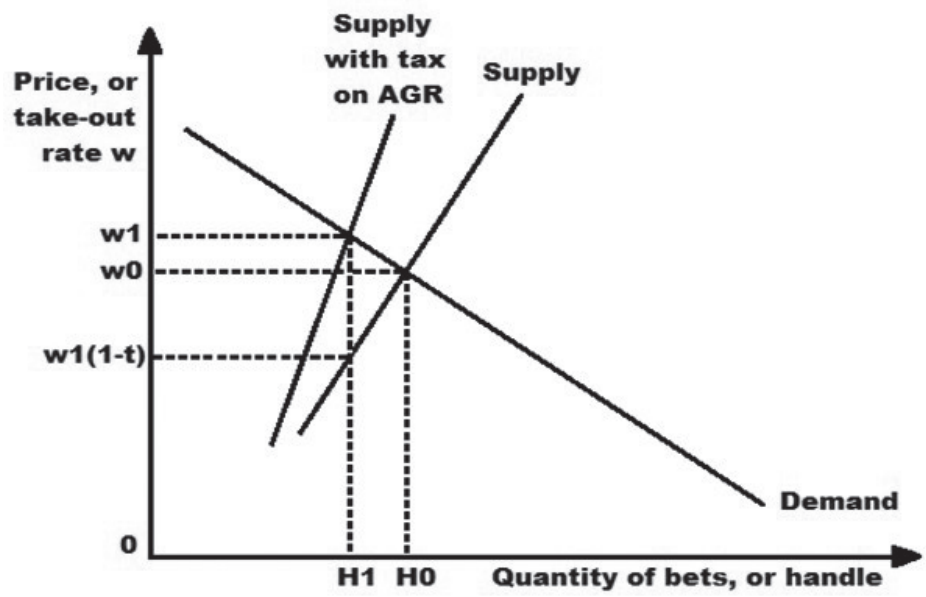

Source: Anderson 2005, p. 316.

Due to the diversity of commercial gambling governments apply various forms of taxation. In the majority of jurisdictions imposing gambling taxes, casinos are taxed on gross receipts collected by them on all the forms of games that they offer. Some countries may in addition levy taxes on slot machines and other electronic gaming machines located in casinos - in most cases as a per-machine license fee [Clotfelter 2005, p. 90]. J. E. Anderson based on his study on the forms of taxes and fees applied to casinos in the United States describes three types of casino levies [2005, p. 306]:

- wagering tax - imposed, depending on the state, on adjusted gross receipts (AGR) or gross gambling receipts minus payouts for prices,

- admission tax - primarily applied in riverboat casino states; currently varying with patronage, size of the facility offering gambling services and the state or local government unit imposing the tax,

- casino fees - in most cases licensing fees imposed by states or local government units (in certain cases taking a form of a tax on casino value).

In economic theory gambling taxes need to be adequately designed for economic welfare maximization or internalization of negative externalities. The fulfillment of the first of these aims is the subject of optimal tax theory. The main question posed by this theory is how best to raise revenues in a distorted economy [Boadway 2012, p. 7]. In such an economy government 
possesses only imperfect information and there is a need to redistribute the income through taxation. In the presence of distortions the optimal outcome is the second-best, that is inferior to the first-best, taking place in a non-distorted economy. The theory assumes that any tax other than a lump-sum tax is the second-best solution because it causes significant welfare loss (deadweight loss) [Stiglitz 2000, p. 550].

The analysis of the economic consequences of casino taxes is illustrated in Figure 1. The horizontal axis presents the total quantity of bets defined as a handle $(H)$, the vertical - the price or in other words the take out rate $(w)$. Due to the fact that the total prizes paid to winners $(P)$ can be defined as the take out rate equals. As the price of gambling is inversely related to the prize amount it can be expected that gamblers will gamble more at lower relative prices. In figure 1 the supply curve is relatively inelastic because governments usually limit and regulate the number and size of casinos. The imposition of a tax on adjusted gross receipts causes an upward shift of the supply curve which results in a higher equilibrium take out rate and lower - handle. The tax increases the price from $w 0$ to $w 1$ and lowers the price received by the casino from $w 0$ to $w 1(1-t)$. The gambler will in the situation demonstrated here bears the tax burden of $(w 1-w 0) H 1$ and the casino $-[w 0-w 1(1-t)] H 1$. The economic agent with the more elastic behaviour will bear the greater share of the tax burden. With regulatory restrictions imposed on casinos their operators will bear a larger share of the tax burden due to the relatively inelastic supply. Deadweight loss generated by AGT applied to casino in Figure 1 is the triangle with height $(\mathrm{t})$ and width (H0 - H1) [Anderson 2005, p. 317].

One of the first authors to discuss the problem of optimal commodity tax rate structure was F. P. Ramsey [1927, p. 58-59]. The rule suggested by this author requires the imposition of tax rates that are inversely proportional to the compensated elasticities of demand for the taxed commodities if they are produced by several different methods or in several different places between which there is no mobility of resources. If there is a correlation amongst the demand for commodities the appropriate tax policy of the gambling market is more complicated. K. S. Philander indicates that if gambling is, for instance, strongly tied to the tourism industry the application of a high tax on casinos may adversely affect tax revenue generated from tourism industry [2012, p. 13].

Another recommendation for the policy ensuring optimal gambling market taxation can be drawn from the Corlett-Hague rule. It implies that the commodity which is a stronger complement (or weaker substitute) of leisure than the other should be taxed more heavily [Zee 2002, p. 74]. According to 
this rule casino gaming could be a potential candidate for relatively higher tax rates (for instance higher than those imposed on lotteries). Such rates may correct the distortions in the customer choice between work and leisure hours [Forrest 2008, p. 553].

Excise taxes are often rationalized as charges for the external costs that consumers or producers of excisable products impose on others. This concept is known as Pigouvian prescription [Cnossen 2005, p. 597]. Due to the fact that casinos may cause social costs that occur as a result of pathological gambling corrective taxation is recommended in economic literature to reduce these costs [Anderson 2013, p. 29]. As the measure of externalities is a function of the level of problem gambling higher tax rates should be applied to those forms of gambling that have more problem gamblers, such as poker [Philander 2013, p. 21].

\section{Casino Taxation in Poland - a Review of the Current Regulations}

The taxing of casinos in Poland has been regulated in the Polish Gambling Law of 19th November 2009, which entered into force on 1st January 2010 [Ustawa $z$ dnia 19 listopada 2009 r.]. This Law introduced a number of restrictions on gambling operators. For example, the Law does not envisage extending permits to organize games in slot machine salons which had been issued before the Law entered into force. Therefore at present casinos are the only entities allowed to organize such games. Moreover the legislator does not allow the organisation of video lotteries. The Law also changed the rules for the organization of poker games in casinos. According to the new regulations casinos may only organize poker tournaments.

The provisions of the Law regulate the organisation of gambling games, applying for licenses and permits, paying fees and taxes, and reporting, as well as sanctions for non-compliance. Gambling games may only be organized in accordance with the rules specified under the Law. The organisation of such games without a valid licence or permit, as well as not reporting or registering a slot machine, or participating in a game organised without a valid licence or permit, is subject to a fine amounting to $100 \%$ of the income from the (won) game. Also organizing machine games outside casinos is penalised with a fine of 12,000 PLN per machine.

Article 4 of the Law includes the definition of a casino. It is a place where cylindrical games, card games, dice games and slot machine games are organised and played in compliance with the approved rules and regulations. The definition also includes a requirement concerning the minimum number of cylindrical games and card games a casino must offer, i.e. 4, and the minimum number of installed slot machines, i.e. 5 to 70 . 
In Poland there may be only one casino per 250 thousand citizens. However the total number of casinos in a province may not exceed 1 per round number of 650 thousand inhabitants. Gambling casinos may also operate on Polish ships and passenger ferries during cruises, but they may not start their activity earlier than 30 minutes after departure from a port and may not continue longer than until 30 minutes before entering a port.

There are two categories of levies imposed on casinos:

- fees, e.g. for a licence or permit to organise a poker tournament,

- gambling tax (also called game tax).

The fee for a licence equals $32000 \%$ of the base amount which is the equivalent of a monthly payment in the enterprise sector for a given calendar year, excluding payments from profit, in the second quarter of the previous year, announced by the President of the Central Statistical Office (GUS) in its Official Journal. As for 2014 the base amount equals 3,785.38 PLN. A fee for a permit to organise a poker tournament equals $100 \%$ of the base amount. Apart from that fees are also charged for issuing professional certificates and in the case of examinations for certain positions and functions which involve supervising gambling.

The lottery and gambling tax is imposed on entities operating in the lottery and gambling market, arranging games within the state monopoly and on participants in poker tournaments. The tax liability arises on the date of commencement of the taxable activity and, in the case of participants in poker tournaments, at the moment of entering a tournament. If it is impossible to determine the date on which the tax liability arose, it is assumed that it occurred on the date when an authorised tax or fiscal body registered the taxable activity or the organisation of the taxable event.

The game tax base is as follows:

- for cylindrical games, dice games and card games, with the exception of the poker game organized as a poker tournament - the amount being the difference between the total cash payments made in exchange for chips at the counter and at the gaming table and the total amounts paid in cash for the chips returned,

- for a poker game organized as a poker tournament - the amount of the prizes less the tournament fee,

- for games on slot machines - the amount being the difference between the amount obtained from the exchange of tokens or paid at the counter and credited in the slot machine memory, or paid into the slot machine and the total of game participants' prizes.

The game tax rates are as follows: 
- for games on slot machines, cylindrical games, dice games and card games, with the exception of a poker game organized as a poker tournament $-50 \%$ of the tax base,

- for poker games organized as a poker tournaments $-25 \%$ of the tax base.

The gambling tax is paid to the account of a competent customs' chambers. The tax payment deadline is the tenth day of the month following the month of the tax settlement. One exception is the tax paid by entities organising poker tournaments. In this case the tax must be paid by the $20^{\text {th }}$ day of the month following the month which the tax settlement concerns. The proper tax authority is the customs' chamber with competency for the location of a given casino.

The legislator imposed on casinos a number of recordkeeping and reporting requirements. Casinos are obliged to maintain books on the sale of sale of chips/tokens and records of cash flows, books registering the operations of slot machines, the records for the gaming tax base and tax due calculation, as well as a registers of tips. Moreover casinos are obliged to submit information concerning their operation on demand to the Minister in Charge of Public Finance and the directors of competent customs' chambers; the information may include economic and financial data breakdowns concerning their current operations and, in particular, their turnover, financial results, economic ratios and notably the headcount ratio, as well as certain statistical indicators.

\section{Casinos in Poland - Scale of Operations, Profits and Tax Due on Gambling Activities}

Casinos constitute one group of several groups of entities operating on the Polish gambling market. In this market there is a state monopoly executed by the Minister in Charge of the State Treasury in the field of number games, cash lotteries and telebingo. Apart from the state, in this market entities operate also which organise mutual bets, also over the Internet, slot machine salons and salons with slot machines with low prizes.

To operate a casino in Poland a company is required to be a joint stock company or a limited liability company, have their place of registration in the country and a share capital of at least 4 million PLN [ECA's European Casino 2013, p. 76]. In 2014 there were 51 gambling casinos in Poland. In all provinces, with the sole exception of one province (Zachodniopomorskie), all the limits assigned for casinos were used (Tab. 1). The most permits were assigned to the most populated provinces (Mazowieckie and Śląskie). 
Table 1. Limits on the number of casinos and the number of casinos by province as of 26/06/2014

\begin{tabular}{|c|c|c|c|}
\hline Province & Population & Casino limit & $\begin{array}{c}\text { Number of } \\
\text { casinos }\end{array}$ \\
\hline Dolnośląskie & 2909997 & 4 & 4 \\
\hline Kujawsko-Pomorskie & 2092564 & 3 & 3 \\
\hline Lubelskie & 2156150 & 3 & 3 \\
\hline Lubuskie & 1021470 & 1 & 1 \\
\hline Łódzkie & 2513093 & 3 & 3 \\
\hline Małopolskie & 3360581 & 5 & 5 \\
\hline Mazowieckie & 5316840 & 8 & 8 \\
\hline Opolskie & 1004416 & 1 & 1 \\
\hline Podkarpackie & 2129294 & 3 & 3 \\
\hline Podlaskie & 1194965 & 1 & 1 \\
\hline Pomorskie & 2295811 & 3 & 3 \\
\hline Śląskie & 4599447 & 7 & 7 \\
\hline Świętokrzyskie & 1268239 & 1 & 1 \\
\hline Warmińsko-Mazurskie & 1446915 & 2 & 2 \\
\hline Wielkopolskie & 3467016 & 5 & 5 \\
\hline Zachodniopomorskie & 1718861 & 2 & 1 \\
\hline Provinces in total & 38495659 & 52 & 51 \\
\hline
\end{tabular}

Source: [Wolne lokalizacje, online].

In 2006-2012 the number of casinos in Poland grew. The increase in the number of licences obtained to operate a casino was especially visible in 2010 . The number of applications for such a licence increased several times in this year. This increased interest in running a casino business remained high also in 2011 and 2012 (Tab. 2) and was a result of the implementation of the Gambling Law which does not envisage the issuance of new licences or the renewal of existing licences for the organisation of games in slot machine salons and salons with slot machines with low prizes. A significant decrease in operations 
especially concerned salons with slot machines with low prizes. Before 1st January 2009 there were 549 existing licences issued for such places; by the end of 2009 their number decreased by 106 entities. Therefore the attractiveness of casinos, as the only places where such games could be organized, increased. However the number of casinos did not grow by the number of licences issued, as only some of them were issued for new locations. Changes in the Law contributed also to the significant increase in the number of slot machines used in casinos (Fig. 2). In 2012, in comparison with the previous year, the number of slot machines in casinos doubled.

Table 2. Casinos in Poland in the years 2006-2012

\begin{tabular}{|c|c|c|c|}
\hline Year & $\begin{array}{c}\text { Number of casinos } \\
\text { operating in a given } \\
\text { year as of 31/12 }\end{array}$ & $\begin{array}{c}\text { Number } \\
\text { of issued } \\
\text { (extended) } \\
\text { licences }\end{array}$ & $\begin{array}{c}\text { Number of entities } \\
\text { operating casinos }\end{array}$ \\
\hline 2006 & 27 & 5 & 5 \\
\hline 2007 & 26 & 1 & 5 \\
\hline 2008 & 27 & 2 & 5 \\
\hline 2009 & 27 & - & 6 \\
\hline 2010 & 33 & 13 & 6 \\
\hline 2011 & 34 & 12 & 9 \\
\hline 2012 & 45 & 17 & 6 \\
\hline
\end{tabular}

Source: Informacja o realizacji 2007, pp. 5-9, Informacja o realizacji 2008, pp. 5-9, Informacja o realizacji 2009, pp. 5-9, Informacja o realizacji 2010, pp. 5-9, Informacja o realizacji 2011, p. 7, Informacja o realizacji 2012, p. 8, Informacja o realizacji 2013, p. 10. 
Figure 2. Number of gaming tables, card tables and slot machines used in casinos in the years 2009-2012

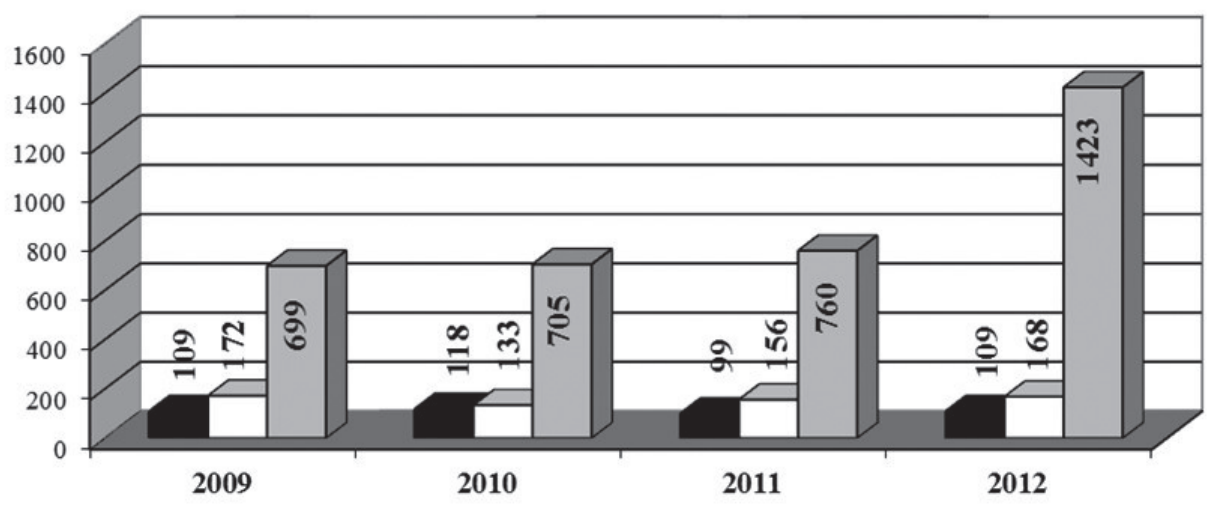

a Tables for cylindrical games $\quad \square$ Tables for card games $\quad$ Slot machines

Source: Informacja o realizacji 2011, p. 11, Informacja o realizacji 2012, p. 13, Informacja o realizacji 2013, p. 15.

Table 3. Revenues of casinos in Poland in the years 2006-2012

\begin{tabular}{|c|c|c|}
\hline Year & $\begin{array}{c}\text { Revenue from } \\
\text { gambling (in } \\
\text { thousands PLN) }\end{array}$ & $\begin{array}{c}\text { Share in revenues by entities organizing } \\
\text { gambling games and mutual bets (in \%) }\end{array}$ \\
\hline 2006 & 1089289 & 13,42 \\
\hline 2007 & 1335411 & 11,16 \\
\hline 2008 & 1354230 & 7,87 \\
\hline 2009 & 1415287 & 6,95 \\
\hline 2010 & 1260292 & 7,76 \\
\hline 2011 & 1293574 & 8,71 \\
\hline 2012 & 1843646 & 12,90 \\
\hline
\end{tabular}

Source: Informacja o realizacji 2009, p. 9, Informacja o realizacji 2011, pp. 11-12, Informacja o realizacji 2013, p. 16. 
Casino operators show limited interest in organizing poker tournaments. Permits for their organisation are granted by the Minister in Charge of Public Finance. In 201016 permits were granted for the organization of these tournaments, in $2011-17$, and in $2012-14$.

Casinos have a significant share in the revenues of entities operating in the market of gambling and mutual bets (Tab. 3). In 2012 this share was higher only for lotteries monopolised by the state and slot machine salons. In 20062012 revenues of casinos increased by about $63.3 \%$. The dynamics of changes in these revenues varied in different years. They increased the most, in comparison to the previous year, in 2012 (by 42.5\%). The implementation of the new Gambling Law contributed to the lowering of the revenues of operators offering services in the gambling market by about $20 \%$. The lowering of these revenues in 2010 concerned all the operators in the gambling market, with the exception of slot machine salons. The revenues of casinos dropped in 2010 by about $11 \%$.

Table 4. Game tax base and tax paid by casinos in Poland in the years 2006-2012

\begin{tabular}{|c|c|c|c|}
\hline Year & $\begin{array}{c}\text { Game tax base } \\
\text { (in thousands } \\
\text { PLN) }\end{array}$ & $\begin{array}{c}\text { Game tax } \\
\text { (in thousands } \\
\text { PLN) }\end{array}$ & $\begin{array}{c}\text { Share in game tax paid } \\
\text { by entities organizing } \\
\text { gambling games and } \\
\text { mutual bets (in \%) }\end{array}$ \\
\hline 2006 & - & 99641 & 10,98 \\
\hline 2007 & - & 122051 & 11,00 \\
\hline 2008 & - & 129707 & 9,04 \\
\hline 2009 & 291911 & 131605 & 8,32 \\
\hline 2010 & 260192 & 127632 & 8,05 \\
\hline 2011 & 256810 & 129461 & 8,73 \\
\hline 2012 & 347827 & 172244 & 12,49 \\
\hline
\end{tabular}

Source: Informacja o realizacji 2009, p. 26, Informacja o realizacji 2011, pp. 11-12, Informacja o realizacji 2013, p. 19. 
The decrease in revenues contributed to the decrease in the gaming tax paid by casinos - by about 3\% in 2010 (Tab. 4). This decline was mitigated by an increase from $45 \%$ to $50 \%$ in the rate of the gaming tax imposed on casinos. The increase in the amount of the gaming tax paid by casinos to the state's budget was visible in 2012 and was related to the increase in the revenues of casinos. In the same year there was an increase in the share of the gaming tax paid by casinos in the total gaming tax paid by all the operators in the gambling and lottery market.

\section{Conclusion}

Nowadays gambling monopolies are regarded as an essential part of excise duties system. They should reduce the social costs of gambling and constitute an efficient revenue raising instrument. Discouraging gambling activities and raising the additional tax revenue were among the most important motives of the introduction of the new Gambling Law by the Polish legislator.

The adoption of this Law contributed to significant changes in the market of gambling operators. In the year following its introduction there was a significant decrease in the revenues of gambling operators, including casinos. However the gradual expiration of permits for the operation of slot machine salons and salons with slot machines with low prizes increased the interest in running casinos. At the same time the number of slot machines used in casinos grew which led to the increase of casinos' revenues and the gaming tax paid by them in 2012 .

The provisions of the new Law regulating the operation of casinos arouse much controversy. They are regarded as extremely strict, in particular the prohibition of playing poker unless within the framework of a poker tournament organised in a casino. The solutions criticized also include unclear regulations concerning the offering and participation in internet games. Internet gambling is, in the light of the new Law, practically illegal. However as the Law in question was adopted in violation of European Community law its provisions may not be fully effective. The criticism of the Law concerns also the fact that it does not envisage the possibility of creating Polish casinos on-line which results in Polish operators losing potential profits from internet games to operators from other countries. 


\section{Bibliography}

Anderson J. E. (2005), Casino Taxation in the United States, "National Tax Journal", Volume 58, Issue 2, p. 303.

Anderson J.E. (2013), The Economics of Casino Taxation,[in:] L. Vaughan Williams, D.S. Siegel (ed.), The Oxford Handbook of the Economics of Gambling, Oxford University Press, Oxford.

Boadway R.W. (2012), From Optimal Tax Theory to Tax Policy: Retrospective and Prospective Views, Massachusetts Institute of Technology Press, Cambridge.

Clotfelter C.T. (2005), Gambling Taxes [in:] S. Cnossen (ed.), Theory and Practice of Excise Taxation, Oxford University Press, Oxford.

Cnossen S. (2005), Economics and Politics of Excise Taxation, "Tax Notes International", Volume 38, Issue 7, p. 594.

ECA's European Casino Industry Report (2013), European Casio Association, Brussels.

Emshoff J. (2008), Gambling and Offending: An Examination of the Literature, Georgia State University, Atlanta.

Forrest D. (2008), Gambling Policy in the European Union: Too Many Losers?, "FinanzArchiv", Volume 64, Issue 4, p. 540.

Informacja o realizacji ustawy o grach i zaktadach wzajemnych $w 2006$ roku (2007), Ministerstwo Finansów, Warszawa.

Informacja o realizacji ustawy o grach i zaktadach wzajemnych w 2007 roku (2008), Ministerstwo Finansów, Warszawa.

Informacja o realizacji ustawy o grach i zaktadach wzajemnych $w 2008$ roku (2009), Ministerstwo Finansów, Warszawa.

Informacja o realizacji ustawy o grach i zaktadach wzajemnych $w 2009$ roku (2010), Ministerstwo Finansów, Warszawa.

Informacja o realizacji ustawy o grach hazardowych $w 2010$ roku (2011), Ministerstwo Finansów, Warszawa.

Informacja o realizacji ustawy o grach hazardowych $w 2011$ roku (2012), Ministerstwo Finansów, Warszawa.

Informacja o realizacji ustawy o grach hazardowych $w 2012$ roku (2013), Ministerstwo Finansów, Warszawa.

Mallach A. (2010), Economic and Social Impact of Introducing Casino Gambling: a Review and Assessment of the Literature, Federal Reserve Bank of Philadelphia, Philadelphia. 
MCP-1050: Casinos - A Global Strategic Business Report, Global Industry Analysts, Press Release [online], http://www.strategyr.com/gia_new/strategyr_new/ pressMCP-1050.asp, dostęp: 20 lipca 2014.

Philander K.S. (2012), The Impact of Casino Tax Policy on Short-Run Gaming Development, University of Nevada, Las Vegas.

Philander K.S. (2013), A Normative Analysis of Gambling Tax Policy, "UNLV Gaming Research \& Review Journal", Volume 17, Issue 2, p. 17.

Ramsey F.P. (1927), A contribution to the theory of taxation, "The Economic Journal', Vol. 37, Issue 145, p. 47.

Stiglitz J.E. (2000), Economics of the Public Sector, W.W. Norton \& Company, New York.

Ustawa z dnia 19 listopada 2009 r. o grach hazardowych, Dz. U. z 2009 r. Nr 201, poz. 1540 , z późn. zm.

Wolne lokalizacje na prowadzenie kasyn gry/województwa i miasta [online] http:// www.finanse.mf.gov.pl, dostęp: 21 czerwca 2014.

Zee H.H. (2002), Theory of Optimal Commodity Taxation [in:] P. Shome (ed.), Tax Policy Handbook, International Monetary Fund, Washington. 